Témoigner Témoigner. Entre histoire et mémoire

Getuigen Revue pluridisciplinaire de la Fondation Auschwitz

$123 \mid 2016$

Traduire le témoignage

\title{
Sandra Ponzanesi. Postcolonial cultural industry: icons, markets, mythologies
}

Palgrave Macmillan, 2014

\section{Caterina Romeo}

\section{(2) OpenEdition}

Journals

Electronic version

URL: https://journals.openedition.org/temoigner/5534

DOI: $10.4000 /$ temoigner.5534

ISSN: 2506-6390

Publisher:

Éditions du Centre d'études et de documentation Mémoire d'Auschwitz, Éditions Kimé

Printed version

Date of publication: 1 October 2016

Number of pages: $213-215$

ISBN: 987 2-9600926-4-6

ISSN: 2031-4183

\section{Electronic reference}

Caterina Romeo, "Sandra Ponzanesi. Postcolonial cultural industry: icons, markets, mythologies",

Témoigner. Entre histoire et mémoire [Online], 123 | 2016, Online since 02 November 2021, connection on 04 November 2021. URL: http://journals.openedition.org/temoigner/5534 ; DOI: https://doi.org/ 10.4000/temoigner.5534

This text was automatically generated on 4 November 2021

Tous droits réservés 


\title{
Sandra Ponzanesi. Postcolonial cultural industry: icons, markets, mythologies
}

Palgrave Macmillan, 2014

\author{
Caterina Romeo
}

\section{REFERENCES}

Sandra Ponzanesi. Postcolonial cultural industry: icons, markets, mythologies. Palgrave Macmillan, 2014, 272 p.

1 Sandra Ponzanesi makes a timely intervention in the field of postcolonial studies - a field in which she is a long-time renowned scholar - by addressing a specific aspect of postcolonial studies that remains undertheorized: namely the capacity of postcolonial cultural production to enact postcolonial resistance at the time of global capitalism, when cultural production (in general, and postcolonial cultural production is no exception) is regulated by the industry's mechanisms and market laws. In the book's six chapters, which explore literary production, literary prizes, films, and adaptations, Ponzanesi argues that a dichotomous system founded on the opposition between resistance to Western hegemony and complicity with it does not adequately represent (or do justice to) the role that a postcolonial cultural production can have in the contemporary world.

2 Countering arguments that the increasing popularization of postcolonial studies has diluted or tamed its resistance to mainstream culture, Ponzanesi maintains that postcolonial studies still retains its oppositional power, despite operating - just like any other field - within a global system and its economic demands. The author also observes that, even though postcolonial studies has received increasing attention and postcolonial cultural production has become successful on a global scale, racism and Eurocentrism have not been eliminated, nor has the contemporary world done away 
with injustice. Being able to see the oppositional role of postcolonial studies and cultural production, therefore, is more than ever necessary.

In Chapter I, "The Postcolonial Cultural Industry: Notes on Theory and Practice", Ponzanesi starts by tracing the expression "culture industry" (Kulturindustrie) back to Theodor Adorno and Max Horkheimer in their Dialectic of Enlightenment (1947). Adorno and Horkheimer's work scrutinizes the relationship between art and production at a time when art - and culture in general - was becoming part of the capitalist system and, as a result, was losing its capacity to critique current political and cultural systems. According to the authors, the cultural industry does not merely satisfy the needs of consumers in a capitalistic society; rather, it produces them. Ponzanesi's historical survey of the notion of cultural history also touches upon Pierre Bourdieu and his "unacknowledged postcolonial sensibility" (23), Stuart Hall's assertion that culture can be a site of resistance as well as of domination, and the influence of cultural studies on the way we define and perceive culture. Culture, Ponzanesi argues, needs to be understood not as a fixed product but as a complex process articulated in a space where conflicting trajectories come together, and where the value of culture itself continuously shifts. In the transition from cultural industry, as theorized by Horkheimer and Adorno, to global cultural industry, "products no longer circulate as identical objects, already fixed, static and discrete, determined by the intentions of their producers"; rather "they spin out of control of their makers" (26) to satisfy market demands.

4 In order to understand the complexity of the process in which cultural value is created, Ponzanesi analyzes how Black and South Asian counter-cultures have been appropriated by Western hegemonic cultures through a process of dehistoricization: they can become exotica because they are separated from the historic context they originate from (Black music is no longer connected to the plantations, and Indian saris are disconnected from British colonialism and Indian nationalism). The presence of "minorities" is tolerated and even desired in certain cultural spaces. However, their inclusion - and the staging of such inclusion - in certain contexts performs a "compensatory function" (Cashmore, Ellis, The Black Culture Industry, Abingdon \& New York: Routledge, 1997, 9). The process of allowing them into certain spaces has in fact confined them to those spaces and excluded them from other social, political, and cultural fields. As a result, Africanness and Indianness have become hip and cool as commodities to be consumed, but this has not led to a deeper acceptance and respect of African and Indian bodies, who continue to be the victims of racism and xenophobia. Ponzanesi further analyzes how these processes of re-Orientalism are not only enacted by Western hegemonic subjects and societies but also by postcolonial subjects. South Asian young, urban subjects employ self-exoticization to create palatable identities that are thus allowed access into cosmopolitan modernity. Indo-chic may well be read as a form of neo-colonialism; through "strategic exoticism" (Huggan, Graham, The Postcolonial Exotic: Marketing the Margins, Abingdon \& New York: Routledge, 2001), however, postcolonial subjects create a distance from the models to which they are asked to conform in order to be able to walk the Western hegemonic stage.

Chapters II, III and IV ("Literary Prizes and the Award Industry", "Boutique Postcolonialism: Cultural Value and the Canon", and "Advertising the Margins: Translations and Minority Cultures") scrutinize the relationship between postcolonial literature and cultural industry, particularly through the institution of literary prizes. 
For Ponzanesi, the fact that major literary prizes (the Nobel Prize for Literature, Booker Prize for Fiction, Man Booker International Prize, Neustadt International Prize for Literature, Pulitzer Prize) have been awarded to writers from the global South has had the positive effect of spreading themes and structures of feeling not rooted in Europe or North America. Nevertheless, she observes that these writers have implicitly been asked to represent their people and their country, which in some way has diverted attention from artistic and literary value for the benefit of social and political issues. Again, the function these authors are asked to perform is "compensatory", and their access to a space previously denied to them (Western literary market) is dependent on them staying confined to specific roles in that space (in this case, the role of political writers and spokespersons of their people).

6 Ponzanesi argues that the sudden recognition of postcolonial writers signals two different trajectories in Western culture. On the one hand, an exoticizing fascination with the "authenticity" of stories now told by "native informants" (Spivak, Gayatri C., A Critique of Postcolonial Reason: Toward a History of the Vanishing Present, Cambridge: Harvard University Press, 1999) - as opposed to colonizers - accompanied by an urge to compensate past wrongs; on the other hand, a desire for postmodern cosmopolitanism. The quasi-sanctification of certain postcolonial authors, who have become instant celebrities, makes it difficult to discern whether their newly acquired status is actually rooted in commercial success or artistic value. Indeed, through a system of advertising and the creation of "brand authors" (76), the publishing industry, in alliance with the literary prize system (and here Ponzanesi goes back to Horkheimer and Adorno's idea of the culture industry), has gone from satisfying the need to creating the demand for a certain kind of cultural production, which has made far-off exotic places easily reachable through literary consumption. Furthermore, literary prizes seldom acknowledge works written in local languages, thus reiterating the prominence of English as a colonial and neocolonial language and preventing any "decolonization of the mind" (see Ng ugî wa Thiong'o, Decolonising the Mind: The Politics of Language in African Culture, Oxford: James Currey, 1989).

7 Ponzanesi argues, however, that once writers have been awarded literary prizes and acquired sufficient notoriety, they can enact - and have in fact enacted - postcolonial resistance. Even mainstream authors such as Salman Rushdie and Arundhati Roy have indeed introduced themes and issues that were previously absent in global literature, and they have stimulated reflections on inequalities and exploitation around the world that are part of a complex colonial legacy. Ponzanesi thus concludes the three chapters by stating that, even when neocolonial mechanisms can be detected in the alliance between postcolonial literature on the one hand, and the publishing industry and the literary prize system on the other, an analysis of contemporary Western literature clearly shows that there has been a shift in the literary paradigm - also thanks to postcolonial literary critics - which allows for forms or postcolonial resistance.

8 Chapter V, "Postcolonial Adaptations: Literary Production and the Film Industry", is entirely devoted to "postcolonial cinema" or, rather, to the way in which films can be analyzed through a postcolonial lens (which is also at the core of Ponzanesi's earlier work: Ponzanesi, Sandra \& Marguerite Waller (eds.), Postcolonial Cinema Studies, London: Routledge, 2011). To this end, Ponzanesi presents a postcolonial analysis of films such as Michael Haneke's Caché, Danny Boyle's Slumdog Millionaire, and Abdellatif Kechiche's Black Venus. She then investigates book and film adaptations to examine to which 
degree the "postcolonial message" is reinforced or weakened in the process. She divides cinematic adaptations into five different categories: adaptations of empire or colonial novels with a critical edge, adaptations of classics through a feminist and postcolonial lens, adaptations of postcolonial literary texts transposed into films by Hollywood or major European film industries, adaptations of postcolonial novels by postcolonial filmmakers, and Bollywood remakes of Hollywood films. Ponzanesi provides interesting case studies for each category and shows how the process of adaptation - and the degree of resistance it carries with it - varies according to the subject who adapts the text and the geopolitical location s/he occupies.

In the last chapter, "Postcolonial Chick Lit: Post-feminism or Consumerism?", the author's feminist analysis comes significantly to the forefront. Ponzanesi reflects upon the possible inclusion of such a highly commercial genre (think of world-renowned novels, films, and TV series such as Bridget Jones's Diary and Sex and the City) in postcolonial literature, and upon its capacity to instantiate postcolonial resistance. The author considers chick lit as a "postfeminist" genre, using Angela McRobbie's understanding of post-feminism as "marked by a new kind of anti-feminist sentiment that cannot be straightforwardly labelled a backlash, but which interacts in paradoxical and ambivalent ways with the legacies of feminism" (164). Chick lit could be considered problematic from a feminist perspective, since it is a commercial genre, largely based on somewhat stereotypical female gender roles. However, Ponzanesi argues that this genre can also promote a feminist debate and agrees with McRobbie that chick lit is not unaware of feminist issues: women's freedom, especially when it comes to education and sexual life, is central and strongly connected to the freedom of consumption. Furthermore, chick lit promotes female characters whose behavior makes the reader/ spectator reflect on women's empowerment and social roles. Ponzanesi illustrates the origin and the rise of chick lit as a Western genre and then moves to South Asian chick lit, produced both in India and in a diasporic context (in the UK and in the USA). The author shows how this genre, by traveling to a different historical and geopolitical context, acquires even deeper social and political functions, since chick lit novels in these places are "not just about consumption, marriage and career but incorporate issues of tradition, modernity, working life and the new emerging sectors for women in India and abroad, and issues of race, class, ethnicity and education" (189).

The Postcolonial Cultural Industry is another important contribution by Sandra Ponzanesi to the rich and controversial field of postcolonial studies. The author prompts critics to be aware of the fact that postcolonial cultural production (like any other kind) is regulated by market laws, which employ processes of exoticization, fetishization and re-orientalization. She also claims that the postcolonial cultural industry contributes to the reshaping of the cultural industry at large through the inclusion and active participation of postcolonial subjectivities who radically challenge Eurocentrism and Western hegemony. At a time when the postcolonial paradigm is deployed to analyze Europe, its culture, and its transformations, it is crucial to understand how postcolonial cultural production, although in many ways complicit with a neocolonial and neoliberal system, can still maintain a critical edge and narrate counterstories in contemporary societies. 